\title{
A POSIÇÃO DA ÍNDIA NA ECONOMIA-MUNDO CAPITALISTA E $O$ DESENVOLVIMENTO DA INDÚSTRIA DE SOFTWARE NACIONAL: A GAIOLA DE OURO
}

Daniela Santos Nunes de Rodrigues ${ }^{1}$ Helton Ricardo Ouriques ${ }^{2}$

Resumo: Este artigo tem como objetivo investigar como a posição estrutural da Índia na economia-mundo capitalista condicionou o desenvolvimento da indústria de software nacional. Por meio da revisão bibliográfica e da análise de indicadores econômicos é mostrada a relação entre os condicionantes sistêmicos e o desenvolvimento da indústria de software indiana. Identificou-se que inicialmente a Índia empreendeu esforços para equiparar o seu desenvolvimento em hardware e software com o de Estados centrais. Contudo, as pressões para a liberalização econômica e a necessidade de sanar o persistente déficit na balança de pagamentos levaram o Estado indiano a investir em uma inserção subordinada na indústria de software internacional.

Palavras-chave: Índia. Indústria de software. Semiperiferia. Desenvolvimento. Crescimento Econômico.

\section{THE POSITION OF INDIA IN THE CAPITALIST WORLD-ECONOMY AND THE DEVELOPMENT OF THE NATIONAL SOFTWARE INDUSTRY: THE GOLDEN CAGE}

Abstract: This article aims to investigate how India's structural position in the capitalist World-Economy has conditioned the development of the national software industry. Through bibliographic review and analysis of economic indicators, we show the relationship between systemic conditions and the development of the Indian software industry. It was identified that India initially made efforts to equate its development in hardware and software with that of central states. However, pressures for economic liberalization and the need to remedy the persistent deficit in the balance of payments have led India to invest in a subordinate insertion in the international software industry.

Keywords: India. Software industry. Semiperiphery. Development. Economic growth.

\footnotetext{
1 Universidade Federal de Santa Catarina, Programa de Pós-Graduação em Relações Internacionais, Florianópolis, Brasil, jolie.sharp@hotmail.com, https://orcid.org/0000-0001-7879017.

2 Universidade Federal de Santa Catarina, Programa de Pós-Graduação em Relações Internacionais, Florianópolis, Brasil, helton.ricardo@ufsc.br, https://orcid.org/0000-0001-7518-3356.
} 
NUNES, OURIQUES

\section{LA POSICIÓN DE LA INDIA EN LA ECONOMÍA-MUNDO CAPITALISTA Y EL DESARROLLO DE LA INDUSTRIA NACIONAL DEL SOFTWARE: LA JAULA DE ORO}

Resumen: Este artículo tiene la intención de investigar cómo la posición estructural de la India en la economía-mundo capitalista ha condicionado el desarrollo de la industria nacional del software. A través de la revisión bibliográfica y del análisis de indicadores económicos, es la relación entre los condicionantes sistémicos y el desarrollo de la industria del software de la India. Se identificó que India inicialmente hizo esfuerzos para equiparar su desarrollo en hardware y software con el de los estados centrales. Sin embargo, las presiones por la liberalización económica y la necesidad de remediar el persistente déficit en la balanza de pagos han llevado ese país a invertir en la inserción subordinada en la industria internacional del software.

Palabras Clave: India. Industria de software. Semiperiferia. Desarroll. Crecimiento económico.

\section{Introdução}

A capacidade dos Estados de fomentarem sob a sua jurisdição qualquer tipo de atividade econômica está intrinsecamente ligada a posição estrutural destes Estados dentro da economia-mundo capitalista. $O$ objetivo do presente artigo é investigar como a posição estrutural da Índia condicionou o desenvolvimento da indústria de software nacional. A Índia figura como um importante ator no cenário político e econômico internacional, sendo caracterizada, de acordo com diferentes vertentes teóricas como uma economia emergente, um país em desenvolvimento, etc. Aqui a caracterizaremos como um Estado semiperiférico, tendo em vista a opção por fazer uso do aporte teórico da Análise dos Sistemas-Mundo. A despeito de como a literatura dentro da política internacional, da economia política ou da geografia se refiram a Índia, é inegável o fato de que esse Estado possui relevância no cenário internacional, não apenas em âmbito regional, mas também globalmente. A Índia possui um considerável desenvolvimento no setor bélico, em especial na área nuclear, bem como no setor farmacêutico e automobilístico. Contudo, ao pensarmos sobre a Índia na atualidade é impossível não associar a imagem do Estado com as Tecnologias da Informação (TI).

A associação da Índia com as TI é um fenômeno relativamente recente e está ligado, mais especificamente, com a indústria de software nacional. As 
exportações dessa indústria tem aliviado as restrições externas ao crescimento do país, que enfrenta déficits históricos em sua balança de pagamentos, de acordo com os relatórios mais recentes do banco central indiano (PRATES, 2012)(RBI, 2019).

É importante registrar que ao utilizar o termo "condicionar" não estamos incorrendo em uma percepção determinista do desenvolvimento de qualquer atividade sob a jurisdição indiana. Contudo, a partir da perspectiva teórica adotada, compreendemos que a posição estrutural de um Estado dentro da economia-mundo condiciona oportunidades e constrangimentos que influenciam o desenvolvimento de todas as atividades dentro de sua jurisdição. A resposta de cada Estado frente a esses condicionantes sistêmicos, depende da conjuntura econômica, política e social doméstica, bem como das próprias capacidades materiais dos diferentes Estados.

Como já mencionado, o propósito deste trabalho é evidenciar de que forma o posicionamento da Índia na economia-mundo capitalista condicionou o surgimento e desenvolvimento da indústria de software deste país. Para tanto, o artigo está organizado da seguinte forma: a) na primeira seção, será feita uma breve descrição e análise da Índia na economia-mundo capitalista, com ênfase na inserção e posicionamento estrutural do subcontinente indiano no sistema interestatal; b) na segunda seção, será discutida a estratégia nacional de desenvolvimento indiana, a partir de 1947, com subseções que versarão a respeito da revolução da informação e da indústria de software local; o desenvolvimento da indústria de software indiana nas décadas de 1970 e 1980; a conjuntura doméstica favorável a partir da década de 1990 até os dias atuais; c) na quarta seção, será feita uma descrição do perfil das atividades desempenhadas pela indústria de software indiana, que expressam os limites colocados a uma inserção de liderança do país no controle das atividades de tecnologias da informação; d) por fim, apresentam-se as considerações finais, com um sucinto balanço dos avanços conseguidos e limitações existentes para o desenvolvimento da indústria de software na Índia. 
A Índia na economia-mundo capitalista: a inserção do subcontinente indiano e a posição estrutural da Índia moderna

O escopo temporal do artigo situa-se no período da Índia independente, pós1947. Contudo, tendo em vista a opção por investigá-lo sob perspectiva da Análise dos Sistemas-Mundo, é relevante que voltemos um pouco na história para compreender a formação do Estado Indiano e a sua forma de inserção na economia-mundo capitalista. Essa inserção está intimamente ligada com a posição da Índia na Divisão Internacional do Trabalho (DIT) e, por conseguinte, com as oportunidades e constrangimentos que moldaram o desenvolvimento da indústria de software sob a sua jurisdição, na contemporaneidade.

O conceito de incorporação trazido pela perspectiva dos sistemas-mundo é referente ao processo de expansão das fronteiras da economia-mundo capitalista para além do continente europeu ${ }^{3}$. O processo de incorporação do subcontinente indiano iniciou em meados de 1750, estendendo-se por volta de um século. Nesse período outras ${ }^{4}$ vastas zonas externas também foram incorporadas dentro do grande processo de expansão da economia-mundo que iniciou por cerca de 1730/1740, motivado por suas pressões internas ${ }^{5}$ (WALLERSTEIN, 2011). Essas pressões se dão quando os principais monopólios da economia-mundo se exaurem, levando a um período de estagnação. A incorporação de novas áreas permite $o$ acesso a fontes de força de trabalho de baixo custo. Isso permite que a média salarial se mantenha baixa, pois compensa o aumento dos salários reais no Centro (SO; CHIU, 1995).

\footnotetext{
${ }^{3}$ Essa expansão foi iniciada no Século XVII e se estendeu até o Século XIX, quando se integraram as últimas áreas do globo ao moderno sistema interestatal (SO; CHIU, 1995).

${ }^{4}$ Entre essas zonas Wallerstein (2011) cita o Império Turco Otomano, partes longínquas da América, o arquipélago da Indonésia e o Império Russo.

${ }^{5}$ De acordo com Wallerstein, o sociólogo estadunidense que preconizou a estrutura e conceitos centrais da análise dos sistemas-mundo, a economia-mundo"[...] É uma grande zona geográfica dentro da qual existe uma divisão do trabalho e portanto um intercambio significativo de bens básicos ou essenciais assim como um fluxo de capital e trabalho. Uma característica definidora de uma economia-mundo é que não está limitada por uma estrutura política unitária. Pelo contrário, há muitas unidades políticas dentro de uma economia-mundo, tenuemente vinculadas entre si em nosso sistema-mundo moderno dentro de um sistema interestatal."(WALLERSTEIN, 2004:19, tradução nossa)
} 
A incorporação implica em duas mudanças essenciais nos lugares afetados. A primeira é a reestruturação dos processos produtivos locais, para que a estrutura produtiva da área incorporada passe a participar de forma responsiva à divisão social do trabalho. Em outras palavras, o processo de incorporação pressupõe que uma determinada localidade se torna uma parte integral para várias cadeias mercantis que constituem a vigente DIT. Complementando essa reestruturação na esfera produtiva, segue-se uma reorganização das estruturas políticas de modo a criar entidades políticas que operem dentro das regras do sistema interestatal, facilitando a participação econômica da nova área na economia-mundo (WALLERSTEIN, 2011).

Sendo assim, o processo de incorporação implicou no fim da autossuficiência do subcontinente indiano, inserindo-o de forma subordinada na economia-mundo. A integração da Índia às cadeias mercantis da economia-mundo capitalista se deu mediante o processo de desmantelamento da pujante indústria têxtil local, transformando-a em uma importadora dos tecidos britânicos (CLINGINGSMITH; WILLIANSON, 2007). De acordo com Wallerstein (2011), o processo de incorporação é seguido de um processo de periferização. Para o autor: "incorporação envolve fisgar a zona para a órbita da economia-mundo de forma que ela [...] não possa escapar, enquanto periferização envolve a transformação contínua das miniestruturas da área de modos que são às vezes referidos como de aprofundamento do desenvolvimento capitalista" (WALLERSTEIN, 2011:130) $^{6}$

A posição estrutural de cada Estado dentro da economia-mundo está ligada de forma intrínseca com o tipo de atividade produtiva que se encontra sob a sua jurisdição. Essas atividades, por sua vez, nada mais são do que nódulos ou elos das diversas cadeias mercantis que atravessam as fronteiras do Estado e os conectam a nível sistêmico política, econômica e socialmente. Observando a DIT,

\footnotetext{
${ }^{6}[\ldots]$ "incorporation involves "hooking" the zone into the orbit of the world-economy in such a way that it [...] can no longer escape, while peripheralization involves a continuing transformation of the ministructures of the area in ways that are sometimes referred to as the deepening of capitalist development" (WALLERSTEIN, 2011:130).
} 
torna-se possível compreender o funcionamento da hierarquia entre o centro, a semiperiferia e a periferia.

Os conceitos de centro e periferia referem-se ao grau de monopólio dos processos produtivos. Dentro da DIT, os processos (ou atividades) produtivos são classificados em centrais ou periféricos conforme o seu grau de monopolização. As atividades centrais desfrutam de quase-monopólios, o que faz com que elas gerem maior valor agregado em relação às periféricas, as quais são verdadeiramente competitivas ${ }^{7}$ (WALLERSTEIN, 2004).

Giovanni Arrighi (1997) analisa o desenvolvimento capitalista tendo por unidade de análise a economia mundial ao longo de quatro ondas longas. Essas ondas longas são um "reflexo temporal dos processos competitivos da economia mundial" (ARRIGHI, 1997:19) e a "alternância entre pressões competitivas mais intensas e mais refreadas é o que entendemos por ondas longas de prosperidade e depressão" (idem, ibidem). Essas ondas longas possuem uma fase A (expansão) e uma fase $\mathrm{B}$ (retração). $\mathrm{Na}$ fase $\mathrm{A}$ as indústrias de ponta se encontram em uma situação de quase-monopólio. $\mathrm{Na}$ fase $\mathrm{B}$ ocorre um acirramento da competição entre as empresas capitalistas e uma deterioração dessa situação de quase-monopólio. Esses ciclos da economia-mundo capitalista, de prosperidade e depressão, levam o nome de ciclos de Kondratiev (K) (ARRIGHI, 1997; WALLERSTEIN, 2004).

Admite-se ainda uma terceira categoria de Estados: os semiperiféricos. O conceito refere-se a Estados que possuem uma mescla relativamente equilibrada entre atividades centrais e periféricas em seu território. É nessa camada intermediária que se encontra o Estado Indiano (WALLERSTEIN, 1979; RUVALCABA, 2020).

Essa compreensão da posição estrutural do Estado Indiano ${ }^{8}$ é imprescindível para uma percepção mais equilibrada de como as oportunidades e

\footnotetext{
8 "No começo do século XXI, alguns países destinados a serem denominados semiperiféricos são Coréia do Sul, Brasil e Índia, países com fortes indústrias que exportam produtos (por exemplo aço, automóveis e medicamentos) para zonas periféricas, mas que também se vinculam de forma habitual com as zonas centrais como importadores de produtos mais avançados" (WALLERSTEIN, 2004, p. 23, tradução nossa).
} 
desafios condicionados por esta influenciaram o desenvolvimento da indústria de software nacional.

Como veremos com maior minúcia nas próximas seções, o desenvolvimento da indústria de software indiana está intimamente ligado com a demanda dos EUA por serviços de software. Em períodos de recessão da economia-mundo capitalista, os produtores, visando a redução dos custos de produção e a manutenção da sua porcentagem do mercado mundial, realocam os nódulos menos rentáveis das cadeias de mercadorias para países com salários mais baixos, mantendo sob a sua jurisdição os mais rentáveis ${ }^{9}$ (WALLERSTEIN, 2004). Foi justamente essa situação que gerou a transferência de parte dos serviços de software para a Índia, gerando uma demanda significativa que serviu, como veremos mais adiante, aos interesses estratégicos do governo indiano.

O estudo do desenvolvimento da indústria de software indiana ilustra de forma clara os entraves e condicionantes decorrentes do embate entre interesses exógenos e endógenos ao Estado semiperiférico, quando este busca desenvolver uma indústria intensiva em conhecimento sob a sua jurisdição. Como escreve Ruvalcaba (2020), em Estados semiperiféricos sempre atuam duas forças polarizadoras contrárias:

"[...] por um lado, as dinâmicas periféricas que subordinam essas zonas às necessidades dos estados centrais, subtraindo sua autonomia; e, por outro lado, os esforços nacionalistas para aumentar a autonomia, manter o estado em um ponto intermediário no continuum hierárquico e, eventualmente, contestar a centralidade do sistema" (RUVALCABA, 2020:22, 2020, p. 22, tradução nossa ${ }^{10}$ ).

Os Estados semiperiféricos tentam se distanciar ao máximo da periferia e se aproximar do centro. "[...] Nenhuma das duas operações é simples e ambas requerem uma considerável ingerência estatal no mercado global"

\footnotetext{
9 Geralmente os nódulos mais rentáveis são os de tecnologia de ponta, caracterizados pelos quase-monopólios e por gerarem alto valor agregado.

10 "[...] on the one hand, periphery dynamics that subordinate these zones to the needs of the core states, subtracting their autonomy; and, on the other hand, the nationalist efforts to increase autonomy, to keep the state at an intermediate point in the hierarchical continuum and eventually to dispute the centrality of the system" (Ruvalcaba, 2020:22).
} 
(WALLERSTEIN, 2004:23) ${ }^{11}$. É isso que faz com que estes Estados empreendam de forma mais ferrenha políticas de cunho protecionista e que digladiem entre si para tornarem-se os herdeiros das indústrias de ponta, assim que estas veem o seu grau de monopólio começar a se erodir.

O processo de recepção dessas indústrias é o que se define amplamente na atualidade como alcançar o desenvolvimento econômico. Nesses períodos ocorre um acirramento da competição entre os Estados semiperiféricos, uma vez que eles não podem ser concomitantemente, ou no mesmo grau, os receptores dessas atividades (WALLERSTEIN, 2004). A capacidade de se tornarem herdeiros das atividades que inicialmente eram realizadas no centro depende da combinação das atividades centrais e periféricas que já fazem parte da jurisdição desses Estados.

$\mathrm{Na}$ sequência do artigo, isso será evidenciado com a descrição de como as políticas pioneiras do Estado indiano em relação aos demais membros da semiperiferia conferiu-Ihe uma vantagem que the permitiu tomar a dianteira entre esses Estados no desenvolvimento da indústria de software, conseguindo uma fatia considerável do mercado de provisão de serviços de software.

\section{A estratégia nacional indiana: um breve relato sobre o período pós 1947}

\section{A Revolução da Informação e a Indústria de Software Global}

O desenvolvimento da indústria de software na Índia se deu em uma fase de retração da economia-mundo, mais precisamente no quarto desses ciclos, segundo Arrighi (1997). Para o autor, a quarta onda longa do capitalismo histórico teve sua fase A em meados de 1939/45. A Revolução da Informação ocorreu nesse período e implicou no desenvolvimento de novas tecnologias que modificariam a forma de comunicação, armazenamento de dados e processamento de informações. Os Estados Unidos assumiram a vanguarda desse processo e isso foi essencial para estabelecer a cooperação e

11 [...] Ninguna de las dos operaciones es sencilla, y ambas requieren de una considerable injerencia estatal en el mercado global (Wallerstein, 2004:23) 
complementariedade entre as grandes empresas estadunidenses e o resto da economia-mundo. Contudo, por volta de $1967 / 73$ os principais grupos empresariais, principalmente do Japão e da Europa Ocidental lograram alcançar os níveis de vantagens organizacionais de suas contrapartes estadunidenses. Por conseguinte, houve um aumento das pressões competitivas que levaram a uma nova fase de retração (ARRIGHI, 1997).

O desenvolvimento da indústria de software em Estados fora do centro da economia-mundo deu-se de forma associada ao modelo estadunidense, com o qual estabeleceram relações de dependência tanto na esfera econômica, quanto na esfera tecnológica. Devido ao caráter trabalho-intensivo de alguns segmentos da indústria de software, esta é comumente vista, dentre a gama de atividades ligadas às Tecnologias da Informação, como a indústria ligada às novas tecnologias com maior possibilidade de êxito ao serem desenvolvidas fora dos Estados do centro (ROSELINO, 2006). O caso de sucesso da Índia, Estado cuja imagem internacional se ligava à pobreza e atraso tecnológico, é recorrentemente apontado como uma evidência disso (STEFANUTO, 2004).

A indústria de software na Índia erigiu-se com foco na exportação de serviços de software (ROSELINO, 2006), por isso iremos nos referir em alguns momentos à Indústria de Serviços de Software. De acordo com SARASWATI (2012), a Indústria de Serviços de Software é um ramo da Indústria de Software que se ocupa da produção de software como um serviço para um único usuário específico. A gama de atividades dentro desse ramo possui um variado grau de complexidade, contudo elas geralmente se enquadram em um dos três setores principais: consultoria em TI, serviços em TI e terceirização de processos em TI.

A Figura 1 esboça a estrutura da Indústria de Serviços de Software e as principais atividades realizadas dentro de cada subdivisão. $O$ autor explica que a terceirização de TI (nível mais baixo do triângulo), abarca as formas mais básicas do processamento e manutenção de dados e as empresas encontram poucas barreiras ao ingressarem nessas atividades, havendo uma competitividade acirrada no ramo. Aqui, a capacidade de ofertar os serviços pelo menor preço é o que normalmente determina qual empresa será escolhida pelos clientes. A 
camada intermediária refere-se ao desenvolvimento de aplicativos de software customizados. Trata-se de uma tarefa personalizada de acordo com as necessidades particulares de cada organização contratante, nesse tipo de atividade existem algumas barreiras para a entrada de novas empresas e a reputação destas é o fator que costuma pesar na escolha dos contratantes. A consultoria de $\mathrm{TI}$ é a camada que mais apresenta barreiras à entrada de novas empresas, uma vez que se trata do fornecimento de serviços com maior complexidade, compreendendo a responsabilidade de fazer o design, bem como a construção de um projeto de TI inteiro. Nesse caso, a experiência com projetos semelhantes e a reputação são os dois fatores que pesam na decisão dos contratantes.

Figura 01 - Estrutura da Indústria de Serviços de Software

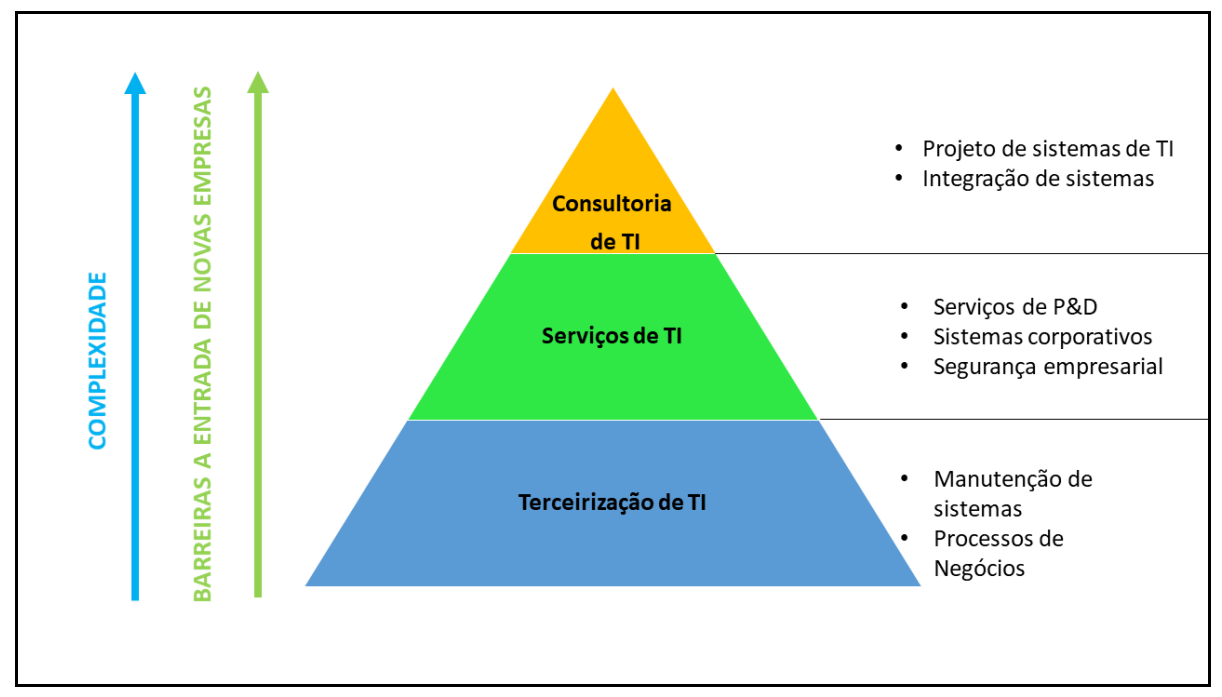

Fonte: adaptado de Saraswati (2012)

A indústria de Serviços de software costuma ser pouco conhecida do público leigo, diferentemente da Indústria de Pacotes de Software. Esta última está envolvida na produção de softwares padronizados para vendas em grande escala. Um exemplo de empresa do ramo, amplamente conhecida, é a Microsoft (SARASWATI, 2012). A própria natureza da Indústria de Serviços de Software contribui para que o público pouco a conheça. Enquanto vários usuários conhecem os pacotes de software da Microsoft, poucos pensam sobre quem 
desenvolveu o sistema por trás do seu banco, da clínica médica a qual frequentam ou mesmo do metrô que utilizam para se locomover.

Para que se possa compreender de forma mais qualificada a posição indiana na Indústria de Software e de Serviços de Software global, faz-se necessário compreender também as etapas de produção de um software. Como explanado anteriormente, a própria incorporação do subcontinente indiano à economia-mundo capitalista se deu mediante a integração da Índia às cadeias de mercadorias dessa economia-mundo. Isso incorreu na reestruturação da economia política local, de forma que esta se tornasse responsiva às dinâmicas e necessidades emanadas do centro. Ao analisarmos o desenvolvimento da indústria de software indiana, estamos de fato analisando um desdobramento dessa dinâmica de relacionamento entre o centro e a semiperiferia. Entretanto, diferentemente de um bem tangível, as fases da produção de um software não são tão claras. Apesar disso, há uma crescente modularização dessa produção que facilita a identificação desse processo. Utilizaremos aqui um modelo simplificado ${ }^{12}$ das etapas fundamentais elaborado a partir de Roselino (2006) e Parthasarathy (2004) e exemplificado na Figura 2.

\footnotetext{
${ }^{12}$ Reconhecemos que um modelo mais fiel a produção de um software incluiria muito mais etapas e que tal processo não ocorre de forma linear como na produção de um bem tangível. Entretanto, para os fins deste trabalho o diagrama fornece as informações necessárias para que compreendamos as etapas cruciais dessa produção, bem como o perfil da força de trabalho necessária para cada uma delas.
} 
NUNES, OURIQUES

Figura 02 - Etapas da Produção de um Software

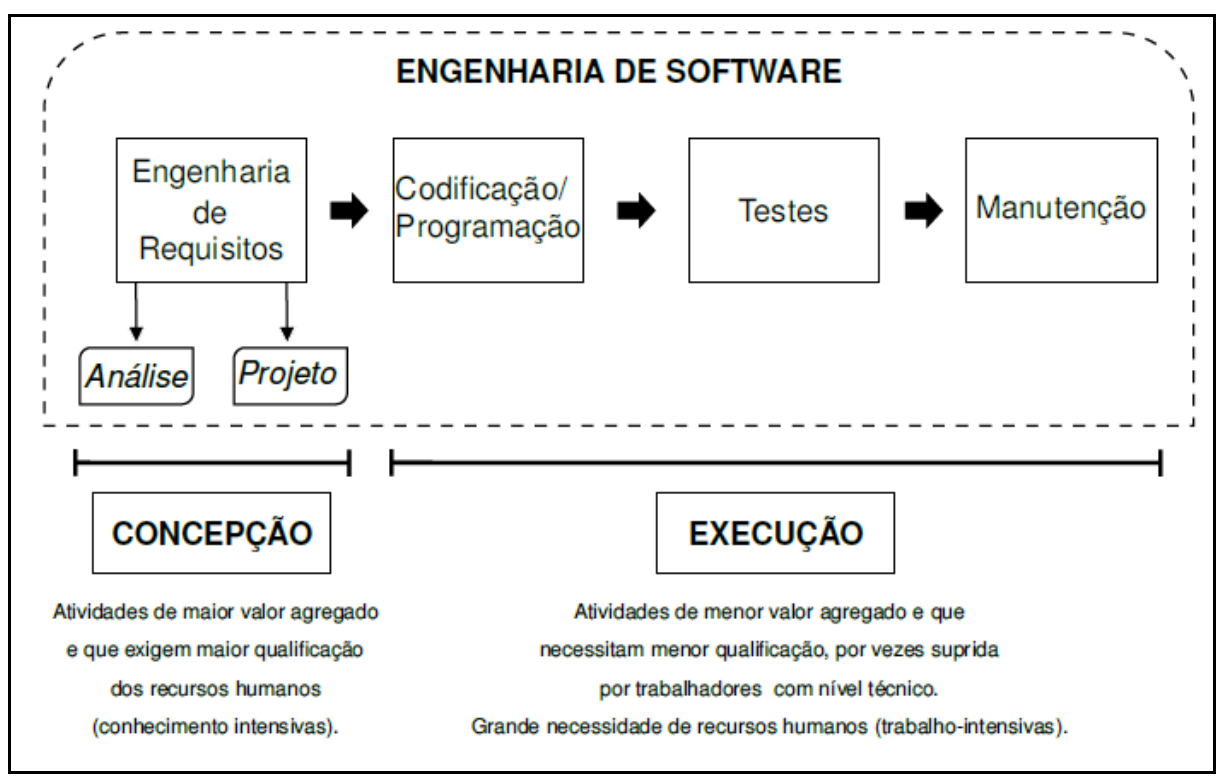

Fonte: Elaborado pelos autores a partir de Roselino (2006) e Parthasarathy (2004)

O entendimento das distintas formas (trabalho-intensivo e conhecimentointensivo) dos diferentes segmentos da indústria de software é crucial para compreendermos a posição da Índia na indústria global de software e as barreiras a sua ascensão para as atividades mais rentáveis e de maior valor tecnológico dentro dessa indústria.

A demanda por serviços de software ganhou impulso na década de 1970. Nesse período, houve um estímulo em âmbito sistêmico para a especialização dos Estados centrais nas atividades ligadas às TI mais rentáveis e complexas. Isso se deu porque as corporações dos EUA estavam sendo pressionadas pelo aumento da pressão competitiva. Além disso, tendo em vista os avanços proporcionados pelas TI e a adesão cada vez maior ao uso de computadores pelo governo e grandes empresas, estas eram incentivadas a fazerem cada vez mais um uso mais amplo dessas tecnologias.

O primeiro computador data de 1947, e o primórdio da indústria de software pode ser datado ao longo do fim da década de 1940 e 1950. No entanto, em seu início, as empresas fabricavam os computadores já com software embutido. Em 1960 a IBM, expoente na fabricação de computadores, decidiu separar a produção de hardware da de software, gerando a primeira grande demanda para serviços de 
software. Nos anos 1970 novos avanços tecnológicos permitiram a fabricação de computadores compactos para uso pessoal (PC). A consequente popularização dos computadores nessa época configurou o segundo grande impulso para a indústria de software (SARASWATI, 2012).

Diante dessa conjuntura, estavam dadas então as oportunidades para que Estados que já possuíssem um certo grau de desenvolvimento tecnológico pudessem se inserir na indústria de software global por meio da provisão de serviços de software para o ávido e amplo mercado estadunidense.

\section{O desenvolvimento da indústria de software indiana nas décadas de 1970 e} 1980

A despeito do êxito da inserção internacional da Índia na indústria de software ser, por vezes, tida como consequência das benesses do processo de liberalização da década de 1990, o marco comumente apontado na literatura especializada $^{13}$ como o símbolo do início dessa indústria foi quando a Tata Consultancy Services (TCS) foi contratada pela Burroughs Corporation dos Estados Unidos para escrever códigos de software para suas máquinas (SINGH e KAUR, 2017).

Nesse período o Estado indiano tinha um perfil altamente intervencionista em todos os setores da economia, como Wallerstein (2004) afirma ser típico dos Estados semiperiféricos ${ }^{14}$. Quando a Índia se tornou formalmente independente da Grã-Bretanha em 1947, quem assumiu o cargo de Primeiro Ministro foi Nehru, que tinha sido um expoente na luta anticolonial ao lado de Gandhi. Durante sua vida política Nehru ancorou os seus discursos nacionalistas em críticas veementes às mazelas causadas pela incorporação do subcontinente indiano à economiamundo capitalista.

\footnotetext{
13 Ver: SING e KAUR (2017); VIJAYASTRI(2013).

${ }^{14}$ Para ele isso se dá porque esses Estados buscam proteger os seus processos produtivos da concorrência com as já consolidadas empresas do centro, ao mesmo em que tentam fortalecer as empresas nacionais, visando torná-las aptas a competir no mercado mundial depois do seu amadurecimento.
} 
Ao estruturar as bases para a construção da economia da Índia moderna, o Partido do Congresso ${ }^{15}$ inspirou-se no modelo da economia planificada da União Soviética, que tinha apoiado abertamente a luta pela independência indiana ${ }^{16}$. Havia um consenso entre os diferentes setores da burocracia estatal, bem como dos partidos políticos, de desconfiança em relação às potências ocidentais e, por conseguinte, à liberalização da economia nacional. Temia-se que a abertura econômica fosse instrumentalizada pelas potências ocidentais para restringir a autonomia do Estado Indiano, dando continuidade à ingerência estrangeira sob novas roupagens (BANIK E PADOVANI, 2014).

O medo dos dirigentes indianos não era infundado. A despeito da conquista formal da autonomia política em 1947, em seus primeiros anos o Estado indiano ainda teve a sua liberdade de conduzir a política doméstica restringida pelos interesses ocidentais (DUTT, 1953). Os EUA, sucessores da hegemonia britânica, inibiram o governo indiano de seguir políticas que fossem contrárias aos seus interesses ${ }^{17}$. Para tal, os EUA manipularam o acesso indiano à comida. Nesse período, a Índia sofria com uma grave insuficiência no provimento de grãos. Outro elemento nesse cenário era a questão do Paquistão ${ }^{18}$, visto como um Estado artificial, formado de acordo com os interesses ingleses para servir de bastião e base para a projeção do poderio bretão e estadunidense na região do Sudeste Asiático e no Oriente Médio (SARASWATI, 2012).

A reação da Índia em relação à primeira questão foi empreender políticas de desenvolvimento agrícola, que culminaram na diminuição drástica de importação de alimentos nos anos 1960 (SARASWATI, 2012). Quanto aos demais setores da economia, adotou-se um modelo econômico baseado na

\footnotetext{
15 Partido de Nehru e um dos dois partidos políticos hegemônicos no cenário político da Índia independente.

16 Nessa época a URSS apoiou o processo de independência de diversos países do então chamado III Mundo.

17 SARASWATI (2012) escreve que um caso emblemático dessa situação foi quando os EUA garantiram que a Îndia aquiescesse com suas operações no Vietnã.

18 É importante salientar que a região que hoje configura o Estado do Paquistão era una com a que hoje forma o Estado Indiano. O processo de separação entre esses Estados ficou conhecido como bipartição e foi fruto da exploração das rivalidades locais pelos colonizadores. Essa separação gerou muitas mortes e levou à criação do Paquistão de maioria religiosa muçulmana, em contrapartida à Índia de maioria hindu. A rivalidade entre ambos grupos religiosos foi uma das peças chave do controle social britânico no subcontinente.
} 
autossuficiência, na economia fechada e na autarquização. Nehru queria garantir a independência do Estado indiano por meio da industrialização induzida pelo Estado com a promoção de um Programa de Substituição de Importações (PSI). Acreditava-se que a industrialização, aliada ao desenvolvimento da ciência e da tecnologia, garantiriam a autonomia estratégica do jovem Estado, bem como a manutenção de uma política externa independente (VIEIRA, 2009).

Nessa época, diversos Estados semiperiféricos e periféricos percebiam a industrialização como sinônimo de desenvolvimento econômico. Não obstante, a industrialização dos países da periferia e da semiperiferia não implicou em uma melhoria na sua posição na hierarquia da riqueza mundial. Isso ocorreu porque as atividades produtivas têm caráter mutável. Os processos produtivos localizados no centro têm a tendência de se "deslocalizarem", ou seja, tornarem-se processos produtivos periféricos ao longo do tempo, quando se esgota a fase de vantagem de superlucros monopolistas ou oligopolistas, e este foi o caso das atividades industriais. Quando uma atividade ascende para o status de centro, inevitavelmente uma ou mais atividades são rebaixadas ao status de periferia. $O$ que ocorre é o deslocamento das pressões competitivas para essas atividades, ou a periferização destas (ARRIGHI, 1997).

No caso da Índia, há um nítido esforço após a independência em transformar a estrutura produtiva do país, através da aceleração da industrialização. A indústria aumenta sua participação no PIB de $16,69 \%$ em $1951 / 52$ para $27,33 \%$ em 1991/92, ficando nesse patamar até o período recente (27,51\% em 2011/12), segundo dados do governo indiano. A agricultura, por sua vez, passa de $41,54 \%$ em 1951/52 para 12,02\% em 2011/12. Notável é o aumento da participação dos serviços na composição do PIB: de 28,94\% em 1951/2 para 58,39\% em 2011/12 (GOI, 2019).

É por isso que Banik e Padovani (2014), chamam a atenção para o fato de que os altos índices de crescimento econômico experimentados pelo Estado indiano atualmente têm sua fonte no setor de TI. Isso diferenciaria a experiência indiana dos casos comumente encontrados na literatura do desenvolvimento comparado, uma vez que o processo se iniciou (pós-independência) no setor 
terciário e seguiu mantido por ele. Essa trajetória distingue-se da usual, na qual observa-se que em sua fase de decolagem os países passam por período de aumento da relevância do circuito manufatureiro.

Mas como isso começou? Apesar de o marco do início da indústria de software indiana ser em 1974, o governo indiano já tinha interesse no desenvolvimento das atividades ligadas à indústria de software desde a década de 1960, o que é percebido por iniciativas como o Comitê Bhabha de 1963, o Comitê de Eletrônicos em 1966, bem como pela Conferência Nacional de Eletrônicos em 1970. Nesse mesmo ano foi criado o Departamento de Eletrônicos (DoE) (SOLANKI; SINHA, 2017), que tinha por objetivo criar e implementar políticas para o setor de TI. Inicialmente essas políticas eram altamente intervencionistas e hostis às empresas multinacionais (SARASWATI, 2012).

No ano de 1972, o governo indiano lançou a primeira política voltada especificamente para a indústria de software nacional, o Esquema de Exportação de Software, que tinha por finalidade a arrecadação de divisas. Esse esquema configurou, muito cedo, a indústria de software indiana orientada à exportação. Essa decisão pioneira é uma das vantagens apontadas para que o país fosse escolhido como provedor de serviços de software para as grandes corporações estadunidenses quando, em um período de retração econômica, as atividades de caráter trabalho-intensivo sofreram o processo de periferização, sendo deslocadas para Estados fora do centro.

A TCS foi a primeira empresa a aderir ao Esquema de Exportação de Softwares. A empresa foi criada em 1968 para aprimorar a gestão de outras empresas do grupo Tata, através do uso das TI. Em 1969 a TCS foi contratada pelo Banco Central da Índia como provedora de serviços de software. Em 1974 a TCS assinou com a estadunidense Burroughs (SARASWATI, 2012). Percebe-se então que o acordo com a empresa estrangeira apenas se consubstanciou graças aos esforços nacionais anteriores, tanto do setor privado, quanto do governo indiano. Esse último agiu não só com incentivos legais e fiscais, mas também gerando demanda para os serviços da TCS, contribuindo para que esta auferisse experiência na área com projetos de grande envergadura. 
Entre junho de 1975 e janeiro de 1977 a jovem democracia indiana passou por um período de exceção que ficou conhecido como Emergência ${ }^{19}$ que implicou em uma transformação na economia política doméstica (NORTON, 2012). Os maiores beneficiários foram os grandes conglomerados industriais, sobre as quais iremos nos referir como Business Houses, que injetaram dinheiro nos maiores partidos do país ${ }^{20}$, com a finalidade de traduzir seu poder econômico em poder político. Ademais, essas empresas se beneficiaram com o boom industrial que ocorreu em decorrência da proibição das greves e o congelamento dos salários. Um dos interesses das Business Houses era a liberalização dos computadores (SARASWATI, 2012).

Em 1976, Indira Gandhi promoveu mais uma série de medidas para liberalizar a política de exportação de computadores. No mesmo ano foram criadas zonas de processamento de exportação, garantindo maior facilidade e rapidez na exportação de softwares. Reduziram-se também para $40 \%$ as tarifas sobre a importação de hardware ${ }^{21}$ (SOLANKI; SINHA, 2017). Em 1978, devido à pressão das Business Houses, lançou-se a Política dos Minicomputadores. Essa política visava, alegadamente, estimular a produção de hardware nacional, aumentando a competição entre as empresas do ramo. Com isso muitas licenças para produtores da área foram concedidas (GOPALKRISHNAN, 2016).

A Política dos Minicomputadores foi desastrosa para a indústria de hardware, mas foi um catalisador do desenvolvimento da indústria de software. Essa política flexibilizou a importação de peças de computadores. Inicialmente acreditava-se que isso garantiria maior competitividade à indústria nacional de hardware. Contudo, o que aconteceu na prática foi que as novas empresas recém licenciadas passaram a importar kits completos de peças estrangeiras e apenas juntá-las, montando o computador em solo nacional, o que por sua vez não gerava inovação e prejudicava o desenvolvimento da indústria de hardware local, cujos produtos eram mais caros. $O$ efeito benéfico para a indústria de software nacional,

\footnotetext{
${ }^{19}$ A Primeira Ministra Indira Gandhi (Partido do Congresso), decretou Estado de Emergência, dissolvendo o parlamento proibindo greves e perseguindo a oposição. (NORTON, 2012).

20 Partido do Congresso e Janata (BJP), ou Partido Nacionalista Hindu.

${ }^{21}$ Anteriormente a tarifa era de $100 \%$.
} 
se deu porque os kits de peças importados pelas novas empresas de hardware indianas não tinham software imbuído. A base de hardware produzida por tecnologia indígena, devido a sua pequena escala, não estimulava as empresas a desenvolverem um software próprio para imbuir em suas máquinas. Sendo assim, configurou-se uma enorme demanda doméstica para a indústria de software nacional (SARASWATI, 2012).

Além de se beneficiar com esse aumento da demanda pela provisão de serviços, não só no âmbito internacional, mas também doméstico, a indústria de software indiana se beneficiou também com o novo direcionamento da economia nacional. A passagem do modelo de economia fechado e baseado no PSI para uma progressiva marcha rumo a liberalização iniciou na década de 1980 e aprofundou-se de forma significativa nos anos 1990. O Estado indiano buscou, através da liberalização, acelerar o crescimento econômico ${ }^{22}$. Apesar disso, todas as medidas liberalizantes foram graduais e marcadas pela forte tutela do Estado, para evitar choques bruscos (AHLUWALIA, 1995). As primeiras reformas tinham por objetivo reorientar a estratégia de exportação para o mercado externo e reestruturar progressivamente a liberdade de competição do setor privado nacional (VIRMANI et al., 2006).

Outro fator que induziu a adoção de medidas liberalizantes foi que, já na década de 1980, intensificaram-se as pressões da classe média pela liberalização das importações dos bens de consumo. O governo optou por liberalizar os bens de capital e matérias primas, para que as empresas nacionais produzissem os bens de consumo desejados. Sem embargo, surgiu um novo paradigma para os gestores da economia indiana. Para compensar a liberalização substancial desses produtos era necessário impulsionar algum produto para a exportação. É aí que o Estado identifica a Indústria de Software como uma área a ser explorada como forma de gerar divisas. Com os avanços no processamento, na rapidez do envio e no baixo custo do envio de dados a longas distâncias, estabeleceram-se

\footnotetext{
22 O padrão de crescimento da economia indiana entre 1950 e 1980 apresentava uma média de crescimento do PIB em torno de $3,7 \%$ ao ano, período em que vigorou a estratégia de desenvolvimento baseada no PSI e na forte ingerência do Estado em todos os setores da economia (PRATES e CINTRA, 2013).
} 
condições propícias para que as empresas indianas passassem a atender cada vez mais as demandas das grandes corporações estadunidenses remotamente. Entretanto, para tal, era imprescindível o suporte do governo central na provisão de infraestrutura doméstica que possibilitasse essa conexão com redes internacionais (SARASWATI, 2012).

O interesse da indústria de software nacional em prover serviços para as empresas estadunidenses, foi de encontro com o interesse do Estado indiano em amenizar os constantes déficits na balança de pagamentos para equilibrar as contas públicas. No Gráfico 1, que traz dados de 1956 até 2006, pode-se verificar o déficit persistente na balança de bens e serviços.

Gráfico 01- Balança de Bens e Serviços Índia (US\$ mil)

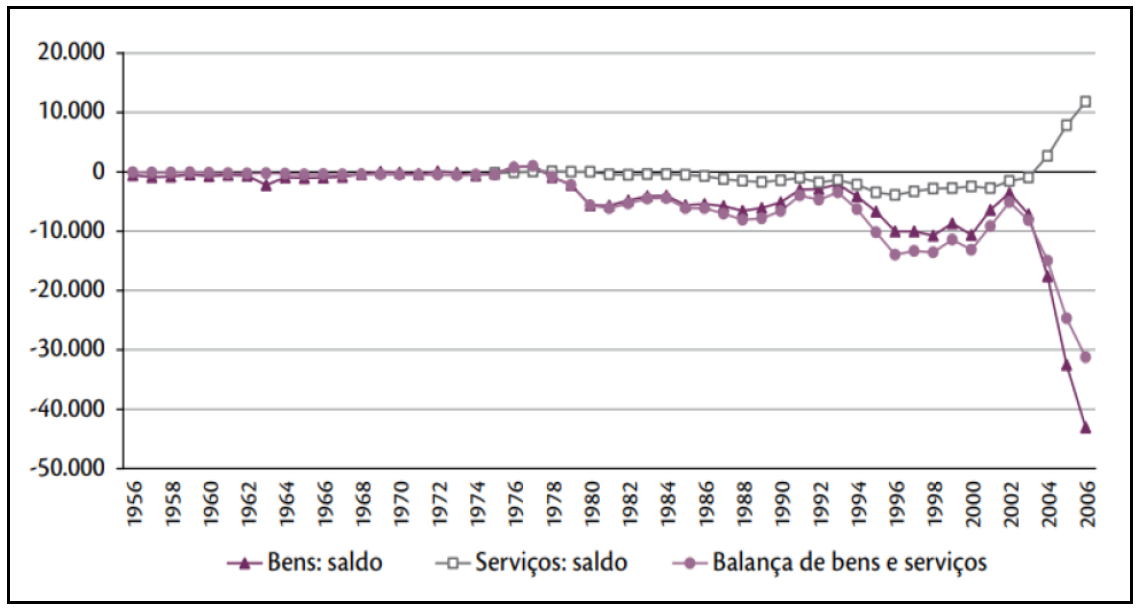

Fonte: Prates e Cintra (2013)

Prates e Cintra (2013) chamam a atenção para o fato de que as exportações indianas com maior teor tecnológico embutido são as do setor terciário, em especial do setor de TI. Os autores creditam essa performance justamente aos estímulos estatais via política industrial, tecnológica e de comércio exterior para o segmento, reiterando que o principal papel da exportação de bens de alta intensidade tecnológica do setor de $\mathrm{TI}$ foi o de aliviar à restrição externa à economia indiana ao assegurar o superávit na balança de serviços, amenizando assim o déficit na balança de bens. 
O Gráfico 1 traz dados até o ano de 2006. Todavia, esse histórico déficit na conta corrente ainda persiste, como evidencia o Gráfico 2, que apresenta dados semestrais do ano de 2013 até o primeiro semestre de 2019. O déficit continua sendo primordialmente impulsionado pelo déficit comercial de bens e apenas parcialmente compensado pelas exportações líquidas de serviços e transferências unilaterais. O saldo final da conta corrente ainda continua negativo.

O estável superávit do setor terciário conseguiu diminuir o déficit no saldo final da conta corrente. No ano de 2017, o Estado indiano figurou como o oitavo maior exportador mundial de serviços (RBI, 2019). A partir da análise do Gráfico 3, é possível afirmar que esse desempenho positivo da exportação de serviços é fortemente ancorado nas exportações de software.

Gráfico 02 - Composição abrangente do déficit da conta corrente da Índia

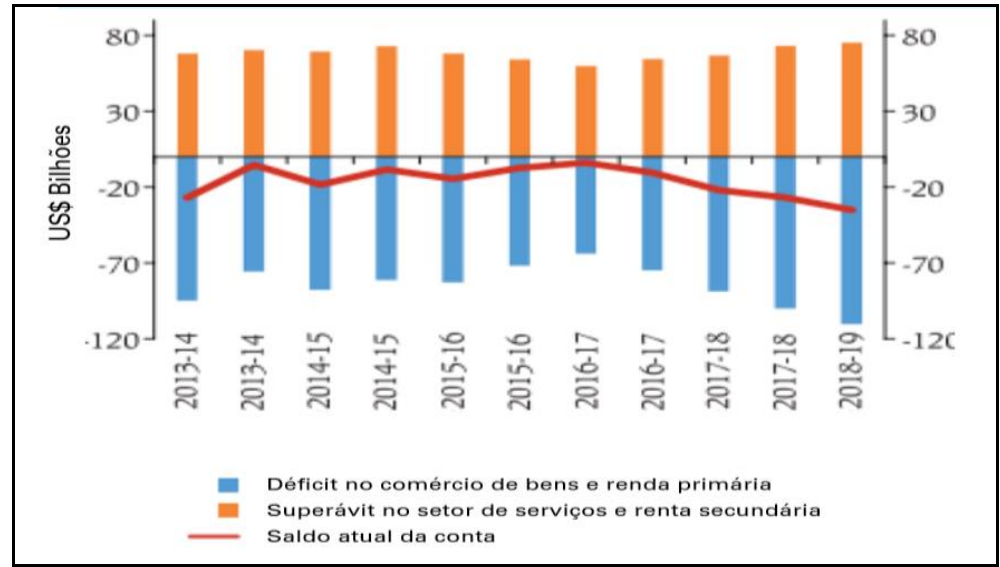

Fonte: Adaptado de RBI (2019).

Gráfico 03 - Principais Exportações de Serviços (2017-2019)

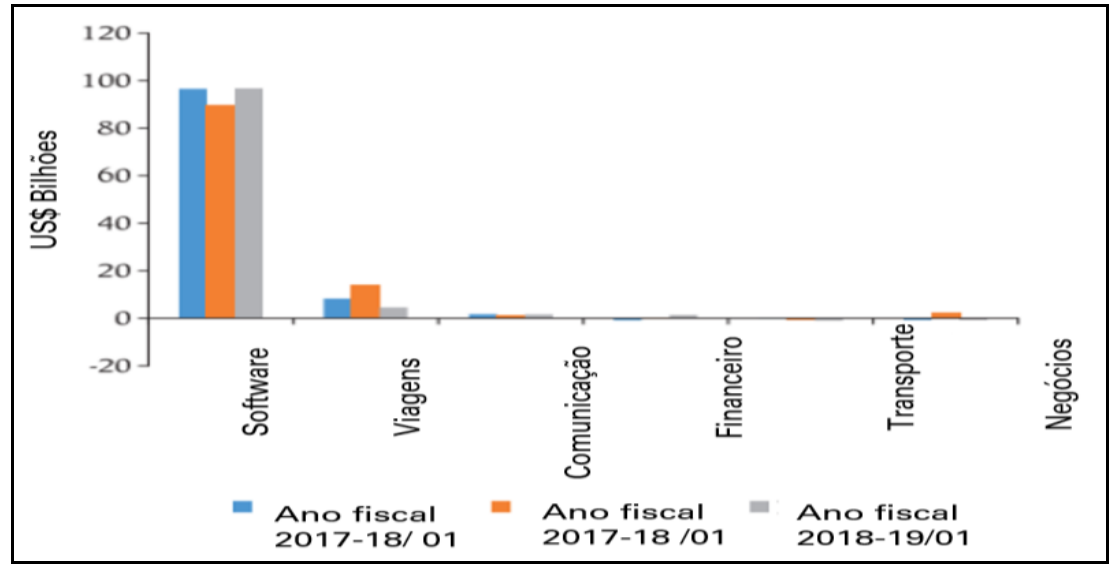

Fonte: adaptado de RBI (2019) 
Visando a instrumentalização das exportações da indústria de software para aliviar a restrição externa ao crescimento, no fim da década de 1980 o Estado assumiu oficialmente a responsabilidade de prover a infraestrutura necessária para que a indústria de software nacional se integrasse à indústria internacional de software, via provisão de serviços de menor valor agregado para o mercado estadunidense (ROY, 2012). Em 1984 lançou-se a Política do Computador Novo, que previa a redução das tarifas ${ }^{23}$ de importação do produto para programadores, além da isenção de impostos e concessão de empréstimos para as empresas de Software. Em 1986 foi lançada a Política de Software, que também tinha por fim promover as exportações do ramo (SOLANKI e SINHA, 2017).

Todas essas medidas demonstram como a indústria de software indiana foi muito precocemente estruturada e voltada à exportação de serviços de software para o mercado estadunidense, configurando uma dependência estrutural em relação a este mercado. Isso fez com que a própria natureza da demanda atendida não estimulasse por si própria a inovação ou o desenvolvimento de atividades de maior complexidade dentro da área. A Índia se especializou principalmente na provisão da parte "braçal" da indústria de software. É importante ressaltar que, inicialmente, essa não era a intenção do governo indiano. Em um primeiro momento a intenção era o desenvolvimento conjunto de uma base de hardware e de software sólidas com tecnologia local. Isso se deu devido ao ideário desenvolvimentista dos primeiros governos indianos (SARASWATI, 2012).

A Índia chegou a produzir computadores bastante avançados. Contudo, diante das mudanças na conjuntura internacional, o país acabou se especializando na indústria de software. Entre as principais causas que levaram isso a ocorrer, destacam-se 1) o esgotamento do modelo econômico voltado para dentro, que tinha por base o PSI; 2) A pressão externa pela liberalização econômica que emergiu na década de 1970, mas ganhou força especialmente nas duas décadas seguintes e 3) a pressão interna da burguesia local pela 
liberalização, a fim de ter acesso aos bens de consumo e de um estilo de vida similar ao das suas contrapartes do centro.

De acordo com dados da Associação Nacional para empresas de Software e Serviços (NASSCOM) de 2019, atualmente os EUA absorvem cerca de $62 \%$ das exportações de serviços de TI da Índia, seguidos pelo Reino Unido (17\%), Europa Continental (11\%), região Ásia Pacífico (8\%) e, por fim, o resto do mundo (2\%).

Como síntese da evolução da indústria de software indiana, apresentamos na Figura 3 a cronologia dos principais marcos dessa indústria no país, a partir dos anos 1950 até os dias atuais.

Figura 03 - Conjuntura sistêmica e marcos da indústria de software indiana

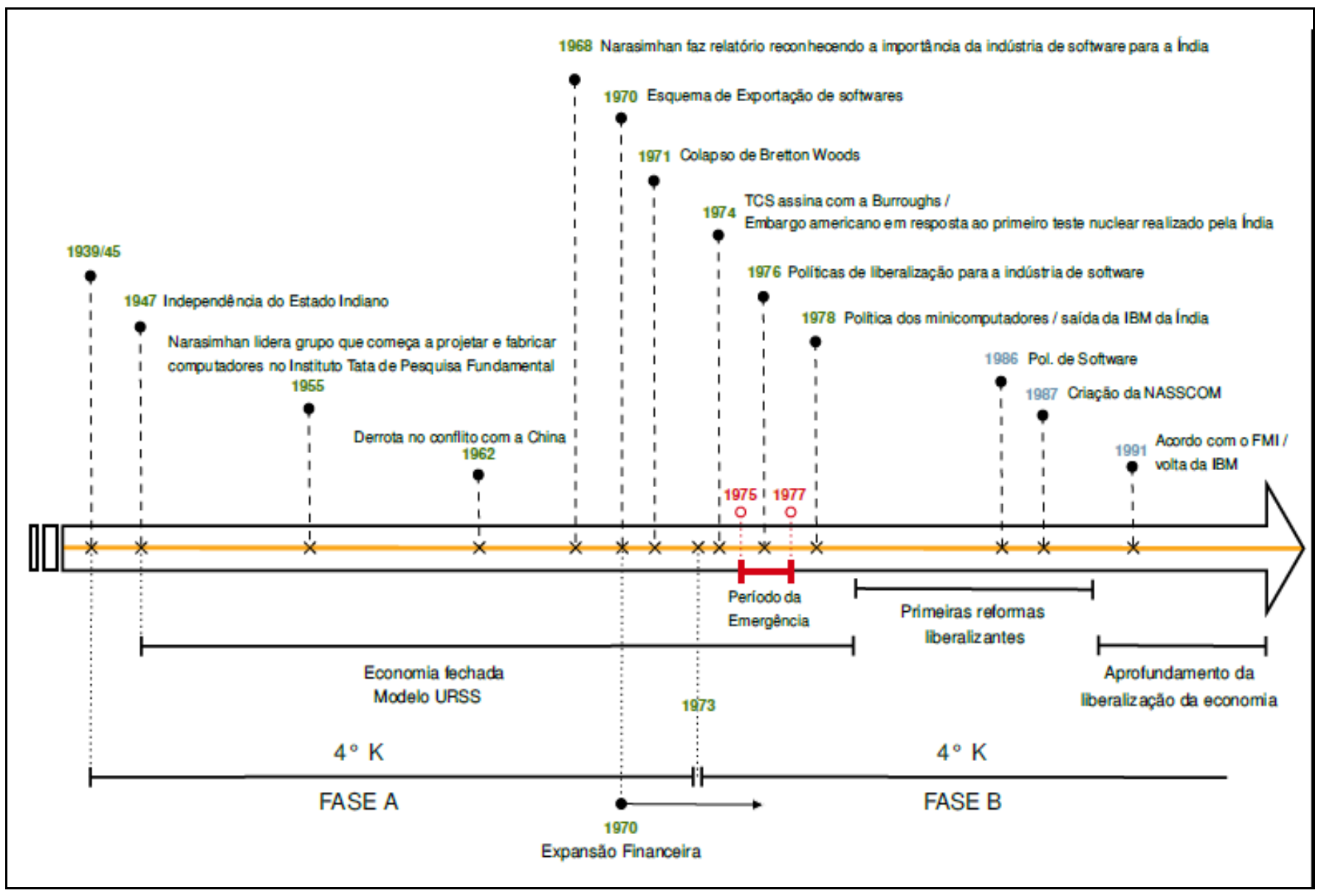

Fonte: Elaboração própria 


\section{A década de 1990 e a conjuntura doméstica e internacional favorável ao desenvolvimento da indústria de software indiana}

Nos anos 1990 a palavra em voga era globalização, e os avanços na indústria de TI permitiram e, concomitantemente, foram moldados pelo processo de mundialização do capital. A forma de organização da produção de diversas indústrias experimentou uma reestruturação, embasada na descentralização da produção tanto no escopo organizacional quanto geográfico. A dissolução da União Soviética parecia ter marcado o triunfo capitalista e do modelo estadunidense de manufatura. $O$ centro desse modelo eram as grandes empresas multinacionais que maximizavam a utilização dos seus recursos instalando filiais nos Estados periféricos com a finalidade de explorar as vantagens de custos destes. O processo de convergência digital (desenvolvimento das tecnologias digitais), tornou-se mais acentuado, bem como aprofundou-se a liberalização dos mercados e foram aumentadas as pressões competitivas (ROSELINO, 2006). Nesse sentido, esse autor explica que:

\footnotetext{
Dentre as primeiras funções externalizadas neste processo estão aquelas ligadas às atividades de informática, delegadas normalmente para empresas especificamente voltadas à prestação destes serviços. Esse movimento estimulou o surgimento de um próspero conjunto de empresas de software, serviços associados e consultoria, inicialmente localizados quase que exclusivamente no mercado estadunidense. Movidos pelas expressivas diferenças internacionais entre custos do trabalho essas atividades de informática deslocaram-se crescentemente para outros países a partir dos anos 1990 [...] (ROSELINO, 2006:62).
}

O autor afirma, portanto, que o movimento de internacionalização produtiva que se intensifica na década de 1990 atuou como um catalisador para o desenvolvimento da indústria de software em outros Estados, abrindo-se a oportunidade inclusive para os Estados periféricos. O desenvolvimento de uma indústria de software robusta implica geralmente na necessidade de um mercado doméstico que ofereça uma demanda grande por esse tipo de atividade. $\mathrm{Na}$ década de 1990, contudo, economias com estruturas produtivas menos desenvolvidas (bem como com avanços limitados na área da eletrônica) conseguiram adentrar à indústria de software. Essa incorporação se deu de forma 
subordinada, ocupando os nichos externalizados pelas corporações estadunidenses, emergindo indústrias de software com um caráter terciário exportador. Roselino (2006) utiliza o termo grifado fazendo uma analogia com o modelo clássico primário exportador dos Estados periféricos, nos quais há a dependência de um centro dinâmico exógeno. Esse tipo de incorporação caracteriza-se, como explanado, pela concentração em atividades trabalhointensivas, com pouca autonomia tecnológica e dependência das necessidades das empresas dos países centrais.

$\mathrm{Na}$ década de 1990 a economia indiana passou por uma reorientação mais intensa, com o Estado conduzindo o aprofundamento das reformas liberalizantes ensaiadas na década anterior (VELASCO \& CRUZ, 2007). Em 1991 o Estado indiano passou por uma crise econômica severa, assinando um acordo com o FMI no ano seguinte, selando o seu compromisso em aprofundar o processo de liberalização econômica.

A difusão das ideias liberais já encontrava eco nos salões da política indiana há algumas décadas e o processo de liberalização, apesar de mais intenso do que o da década anterior, seguiu um ritmo cauteloso e foi cuidadosamente tutelado pelo Estado, sem choques abruptos como no caso dos países latino-americanos ${ }^{24}$.

A área de $\mathrm{TI}$ como um todo e, mais especificamente, a indústria de software nacional, foram grandes beneficiárias desse processo. O governo deu continuidade ao fomento da indústria de software e em 1991 foram criados os Parques de Tecnologia de Software na Índia (STPI) sob a égide do Departamento de Eletrônica e de Tecnologia da Informação. Os STPI são uma iniciativa voltada $100 \%$ à exportação e com o objetivo de tinham como objetivo fornecer a estrutura necessária para o desenvolvimento e a exportação de produtos e serviços de software $^{25}$ (SOLANKI; SINHA, 2017).

As políticas de incentivo foram frutíferas, o setor de TI passou a aumentar progressivamente a sua participação no PIB, como explicitado no gráfico 04 :

\footnotetext{
24 A Índia, por exemplo, recusou-se a aderir a onda de privatizações, optando pelo gradual desinvestimento do Estado em setores selecionados.

25 Informações retiradas do site oficial dos STPI.
} 
NUNES, OURIQUES

Gráfico 04 - Porcentagem da contribuição do setor de TI para o total do PIB indiano

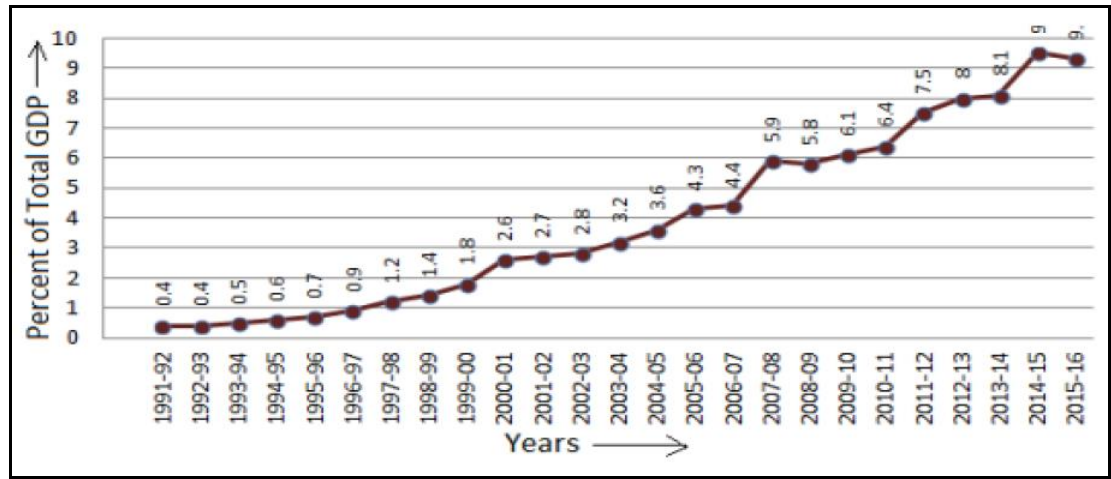

Fonte: Singh e Kaur (2017)

De acordo com dados da OMC (Organização Mundial do Comércio), a participação da Índia no total das exportações mundiais de serviços de informação, de telecomunicações e de computadores no ano de 2017 chegou aos 10,4\% (RBI, 2019). Na Tabela 1 podemos ver que, uma vez que os EUA são os maiores demandantes dos serviços de software indianos, a maior parte da receita auferida por essas exportações recebe dólares como contrapartida. No ano fiscal 2017-2018 as exportações de software renderam cerca de 78,8 bilhões de dólares e, no ano seguinte por volta de 85 bilhões de dólares. Na tabela podemos ver também que a segunda moeda mais importante na composição das receitas da exportação de software é o euro, uma vez que a Europa é o segundo maior destino das exportações de serviços de software indianas.

Tabela 01 - Composição das divisas das exportações de serviços de software

\begin{tabular}{lc|c|cc} 
Moeda & \multicolumn{2}{c}{ 2017 - 2018 } & \multicolumn{2}{c}{ 2018 - 2019 } \\
\hline & Bilhão US\$ & Parcela (\%) & Bilhão US\$ & Parcela (\%) \\
USD & 78.8 & 72.7 & 85.0 & 72.1 \\
EUR & 8.5 & 7.8 & 11.3 & 9.6 \\
GBP & 7.5 & 6.9 & 7.9 & 6.7 \\
INR & 5.0 & 4.6 & 5.3 & 4.5 \\
AUD & 3.2 & 3.0 & 3.5 & 2.9 \\
Outras Moedas & 5.4 & 5.0 & 4.8 & 4.2 \\
\hline TOTAL & $\mathbf{1 0 8 . 4}$ & $\mathbf{1 0 0 . 0}$ & $\mathbf{1 1 7 . 9}$ & $\mathbf{1 0 0 . 0}$
\end{tabular}

Fonte: Reserve Bank of India. Relatório de pesquisa sobre exportações de software e serviços de TI: 2018-19 publicado em dezembro de 2019

Apesar de a indústria de software e demais atividades ligadas às TI não serem capazes de absorver a grande massa de força de trabalho não qualificada 
na Índia, elas têm um importante papel na geração de empregos diretos e indiretos, principalmente para os profissionais com nível técnico e superior.

\section{A gaiola de ouro: o perfil das atividades desempenhadas pela indústria de software indiana}

A indústria de TI configura umas das mais importantes na geração de tecnologia e atração de capital estrangeiro e teve um papel expressivo na contribuição para o acentuado crescimento econômico indiano nas últimas décadas. (NASSIF, 2006). O desenvolvimento dessa indústria estimulou 0 crescimento da educação técnica na Índia, e o fornecimento de infraestrutura digital. A produtividade dos segmentos de $\mathrm{TI}$, inclusive da indústria de software nacional, é maior do que das demais indústrias indianas, principalmente as do setor secundário. Contudo, as suas relações e spin-offs para o sistema de inovação indiano têm sido restritas. Apesar do crescimento acentuado pósreformas da década de 1990, a evolução do setor tem desempenhado um papel muito específico na indústria de software global, concentrando-se em atividades de relativo baixo valor agregado. Isso faz com que o país esteja, de certa forma, confinado a uma posição desvantajosa na divisão global do trabalho (KRISHNAN, 2003). Essa posição "travada" que impede o avanço para as atividades mais rentáveis dentro da indústria de software global está intimamente ligada à dependência do setor exportador e, por conseguinte, dos clientes estrangeiros (D'COSTA, 2004; PARTHASARATHI e JOSEPH, 2004). Como exposto, o destino das exportações de software indianas são, majoritariamente, os EUA, como tem sido desde os primeiros estágios do desenvolvimento da indústria de software nacional.

Incialmente, o mercado nacional para esse tipo de atividade era bastante reduzido. Contudo, essa realidade vem mudando, tendo em vista que a ampliação da infraestrutura digital permitiu uma maior difusão das tecnologias digitais entre a população local. Apesar disso, o foco da indústria nacional (que garante os lucros das empresas nacionais do setor) ainda é a exportação. É essa dependência da exportação que, para D'costa (2004), edifica barreiras estruturais à inovação. A 
terceirização de determinados serviços de software para a Índia por parte das grandes corporações estadunidenses foi, sem dúvidas, rentável para muitas empresas nacionais e atuou como uma fonte de divisas necessárias para sanar o déficit no balanço de pagamentos. Entretanto, ela gera oportunidades e constrangimentos para o desenvolvimento da indústria de software indiana. Ao mesmo tempo em que as empresas nacionais conseguem adentrar nichos de mercado até então não acessíveis, elas também acabam constrangidas a ocuparem-se apenas das atividades que o Centro deseja transferir para a periferia. Essa situação ocorre com todas as indústrias de ponta que são transferidas para a semiperiferia, e posteriormente para a periferia, em períodos de retração da economia-mundo.

As atividades econômicas tendem a ser periferizadas ao longo do tempo (quando deixam de render superlucros), não existindo qualquer atividade que seja permanentemente típica de centro. Ou seja, uma determinada atividade é objeto de transferência geográfica quando se torna mais competitiva. A indústria de software não é exceção. As empresas privadas priorizam seus lucros, portanto acabam por se especializar no que é rentável para elas e que permite a continuação das suas funções. $O$ avanço para atividades com maior teor tecnológico nem sempre gera mais lucro, principalmente no início, pois envolve maiores dispêndios seja com treinamento de pessoal, seja com Pesquisa e Desenvolvimento. Sendo assim, normalmente faz-se necessário que o Estado interfira e promova políticas de incentivo a essas atividades nas quais os interesses privados não se aventuram. Ficou claro, ao longo das seções anteriores, que as políticas estatais foram cruciais para o desenvolvimento da indústria de software nacional em seus estágios iniciais, mas também ao longo de todo o seu amadurecimento.

Essa dependência do mercado estadunidense, que afeta a capacidade de inovação da indústria de software indiana, está relacionada também com a própria posição estrutural da Índia na economia-mundo capitalista. Nos Estados semiperiféricos é comum o desenvolvimento de métodos de produção e formas organizacionais nos mais diferentes setores da economia, que são 
essencialmente repetitivos, não inovadores. Tratam-se de adaptações do que já foi desenvolvido e aperfeiçoado por Estados do Centro (RUVALCABA, 2020).

$O$ foco no mercado externo em detrimento do interno configura um dos maiores empecilhos ao espraiamento de spin-offs de soluções de software para os outros setores da economia nacional (D'COSTA, 2004). No início dos anos 2000, grande parte dos serviços prestados pelas empresas de software locais não necessitavam de engenheiros de software para serem realizadas, devido ao caráter relativamente simples das atividades comumente desempenhadas por essas empresas. Isso se dava justamente pela natureza da demanda atendida por grande parte das pequenas e médias empresas indianas de software (ARORA e ATHREYE, 2002).

$\mathrm{Na}$ análise de dados mais recentes, apresentados na Tabela 2, é possível constatar que essa realidade pouco se alterou. A indústria de software indiana, de um modo geral, manteve a sua especialização na provisão de softwares customizados, não no desenvolvimento de pacotes de software ou software produto.

Tabela 02 - Exportação da indústria de software indiana: receitas por segmento

\begin{tabular}{lcccc} 
Atividade & \multicolumn{2}{c}{ 2017 - 2018 } & \multicolumn{2}{c}{ 2018 - 2019 } \\
\hline & Bilhão US\$ & Parcela (\%) & Bilhão US\$ & Parcela (\%) \\
A) Serviços informáticos & 74.0 & 68.2 & 79.8 & 67.7 \\
Das quais : i) Serviços de TI & 70.3 & 64.9 & 76.2 & 64.6 \\
ii) Desenv. de Prod. de Software & 3.7 & 3.3 & 3.6 & 3.1 \\
B) Serviços habilitados de TI & 34.4 & 31.8 & 38.1 & 32.3 \\
Das quais : i) Serviços BPO & 26.7 & 24.7 & 29.3 & 24.8 \\
ii) Serviços de Engenharia & 7.7 & 7.1 & 8.8 & 7.5 \\
\hline Exportação total (A+B) & $\mathbf{1 0 8 . 4}$ & $\mathbf{1 0 0 . 0}$ & $\mathbf{1 1 7 . 9}$ & $\mathbf{1 0 0 . 0}$
\end{tabular}

Fonte: Reserve Bank of India Survey on Computer Software and Information Technology-Enabled Services exports 2019-2019.

$\mathrm{Na}$ Tabela 2, as exportações de software estão divididas em dois grupos, o de Serviços Informáticos, ou de computadores (que engloba serviços de TI e o desenvolvimento de produtos de software) e o de ITES (que abrange serviços de $\mathrm{BPO}^{26}$ e de engenharia). Os Serviços Informáticos contribuem com cerca de $67,7 \%$ do total das exportações, totalizando quase 80 bilhões no ano fiscal 20182019. Contudo, a atividade de desenvolvimento de software produto, que se trata

\footnotetext{
${ }^{26}$ Sigla referente a Business Process Outsourcing, ou Terceirização de Processos de Negócio.
} 
de uma atividade de maior valor agregado e maior complexidade tecnológica, contribui com apenas $3,1 \%$ do total. A mesma situação ocorre ao verificarmos os valores provenientes dos Serviços habilitados de TI. A maior parte dos rendimentos das exportações advém dos serviços de BPO, não de engenharia. Para compreendermos o que querem dizer estas informações, faz-se necessário lembrar da Figura 1, apresentada na Seção 3.1.

Diante desses dados, vemos que a soma dos serviços de TI (camada intermediária da figura) e de BPO (camada inferior da figura) representa 89,4\% das exportações da indústria de software indiana. Ou seja, quase $90 \%$ das exportações se concentra nas duas camadas de menor valor agregado dentro da indústria.

Ao examinar especificamente os ITES, como aponta relatório do Banco Central Indiano do ano de 2019, 77\% das receitas das exportações são provenientes dos serviços de BPO, que são os de menor valor agregado dentro da indústria de software. Apenas $23 \%$ se concentram em atividades de serviços de engenharia.

D'costa (2004) via a exacerbada dependência nas exportações para os Estados Unidos uma das maiores barreiras ao pleno desenvolvimento da indústria de software nacional, e a necessidade de diminuir essa dependência também foi apontada por Sridharan (2004); Parthasarathi e Joseph(2004); e Saraswati (2012). Para D'costa (2004), a diversificação dos mercados de exportação era imperativa para avançar para atividades mais rentáveis na área e que, para tal, seria necessário a presença do Estado, com o objetivo de implementar um conjunto de estratégias coerentes e de longo prazo para realizar essa transição para atividades de maior valor agregado, ou o topo do triângulo da Figura 1.

Porém, como é evidente no caso indiano, o grau de autonomia do Estado para a manutenção desse tipo de estratégia que rivaliza com os interesses do centro (ou das grandes corporações com sede no centro) varia de acordo com a conjuntura internacional. Isso em especial é verdade em relação à manutenção das estratégias dos estados semiperiféricos que, de acordo com Wallerstein (2004) são, intrinsecamente, zonas de instabilidade política. 
Apesar da dependência dos clientes estadunidenses e europeus continuar acentuada, o mercado doméstico apresentou um crescimento bastante importante desde a década de 1990. A disseminação do acesso à internet e a aparelhos celulares teve um grande papel nesse processo. Atualmente apenas cerca de $36 \%$ da população indiana tem acesso à internet, mas isso corresponde a aproximadamente 451 milhões de usuários, tendo, portanto, uma ampla possibilidade de expansão (MANDAVIA, 2019). O número de usuários de telefone celular é ainda maior, totalizando por volta de 813,2 milhões (STATISTA, 2020). Apesar disso gerar uma gama de oportunidades para o desenvolvimento de aplicativos de software para esses usuários, o setor de sistemas operacionais (software-produto, atividade de maior valor agregado, conhecimento-intensiva) para smartphones ainda é dominado por empresas estrangeiras como a Microsoft, Apple, Sony e Google. A Índia ainda não desenvolveu um sistema operacional para tablets e smartphones como o Android, e tenta trabalhar no desenvolvimento de um similar.

Já em relação a sistemas operacionais de computadores, a Índia vem tentando desenvolver uma versão nacional. O governo tem incentivado o empreendimento ao promover políticas e programas de iniciativo para a adoção de software livre, visando diminuir a dependência da importação de software produto. SOLANKI e SINHA (2017) escrevem que duas das iniciativas principais foram a promoção do sistema operacional indiano BOSS e o Centro Nacional de Recursos para Software Livre e de Código Aberto de 2005 (NRCFOSS6), ambas criadas sob a égide do Departamento de Eletrônicos e Tecnologia da Informação (antigo DoE).

É possível afirmar, portanto, que apesar da situação geral não ter se alterado, o governo indiano vem empreendendo tentativas de fomentar 0 desenvolvimento das atividades de maior valor agregado dentro da indústria de software É importante lembrar que a Índia possui a capacidade técnica para o desenvolvimento de pacotes de software, inclusive produzindo para o mercado doméstico pacotes de software no estado da arte, quase na sua totalidade sendo usados pelo setor público ${ }^{27}$, mas alguns chegando a ser exportados. Esses

${ }^{27}$ Como a CMC, TCIL, Bharat Eletronics e ECIL. 
pacotes, em sua maioria, foram desenvolvidos por instituições de Pesquisa e Desenvolvimento ou por empresas públicas. Entre os projetos com alta complexidade desenvolvidos por empresas indianas destacam-se a automação de aeroportos e portos (PARTHASARATHI, 2004). Não obstante, a situação geral é que as empresas da indústria de software nacional não desenvolvem esse tipo de atividade.

Devido à progressiva periferização das atividades mais básicas dentro da indústria de software, a Índia tende a enfrentar uma competição cada vez maior de outros Estados semiperiféricos (e também periféricos) nesses segmentos. Para manter a lucratividade dessa importante indústria, torna-se cada vez mais necessário avançar para atividades mais complexas, nas quais as pressões competitivas são menos intensas. O desenvolvimento de sistemas operacionais (software-produto) tanto para computadores quanto para celulares com foco no mercado nacional parece ser uma boa aposta. A Índia rivaliza com a China na posição de Estado mais populoso do mundo, e as políticas de inclusão digital para essa grande população aumentam expressivamente as possibilidades de expansão do mercado doméstico para as atividades mais complexas da indústria de software. Além do mais, a especialização no desenvolvimento de softwareproduto tem a capacidade de qualificar e diversificar a pauta exportadora da indústria de software nacional, facilitando a captação de novos clientes estrangeiros, que não as empresas estadunidenses e europeias (cujo perfil da demanda se concentra nas atividades mais básicas).

Atualmente observa-se mais um processo de grande envergadura no âmbito da economia-mundo: a emergência de um novo padrão técnico-produtivo, ou o chamado advento da indústria 4.0. A Indústria 4.0 resulta da incorporação e do desenvolvimento de um conjunto de tecnologias de base digital (IEDI, 2018b). Essas tecnologias congregam os avanços na área das $\mathrm{TI}$, das comunicações, da biotecnologia, entre outras. A novidade da indústria 4.0 não é o uso dessas tecnologias em si, mas a combinação delas e a adição de um novo elemento: o software de inteligência artificial. 
Diante desse novo paradigma tecnológico, além do desenvolvimento de novas tecnologias de alta complexidade como o caso da Inteligência Artificial, é necessário, além de uma série de ajustes organizacionais e institucionais, o desenvolvimento de uma base de tecnologias digitais sólida. Nesse sentido, o desenvolvimento de uma indústria de software robusta, competitiva e inovadora poderia configurar uma possível vantagem no fomento da indústria $4.0 \mathrm{em}$ países semiperiféricos. A Índia lançou o programa Make in India em 2014, um plano multissetorial com diretrizes para o desenvolvimento, entre outras áreas, da indústria de software e revitalização da indústria de hardware nacional. 0 ambicioso plano tem por objetivo transformar a Índia em um centro da manufatura mundial, tornando o setor secundário o centro da economia, diminuindo a dependência das exportações de software para mitigar o constante déficit na balança de pagamentos. É importante lembrar que as exportações de software conseguem apenas amenizar esse déficit.

\section{Considerações Finais}

Esse artigo foi construído com o objetivo de investigar como a posição estrutural da Índia na economia-mundo capitalista condicionou o desenvolvimento da indústria de software nacional. Ao longo do estudo, foi possível constatar que o período de retração da economia-mundo que começou na década de 1970 foi o que deu impulso à transferência das atividades mais básicas da indústria de software para a Índia. Em conjunturas como esta, é comum que vários Estados semiperiféricos compitam para tornarem-se os herdeiros dessa indústria de ponta que está passando por um processo de periferização.

Nessa conjuntura, percebemos que a Índia conseguiu se inserir na indústria de software global (ainda que de forma subordinada) e preservar uma parcela significativa desse mercado (principalmente nas camadas inferiores e intermediárias em teor de complexidade técnica). Isso foi possível pelas políticas pioneiras do Estado indiano para a criação de uma indústria de software e, igualmente, pela sua vanguarda em erguê-la 
voltada ao mercado externo. Os avanços na área da informática que permitiram a separação do desenvolvimento de hardware e software também tiveram um papel importante na criação de demanda por serviços de software, contribuindo para que estas atividades pudessem ser realizadas pela Índia.

É importante registrar que, inicialmente, o Estado indiano tinha um projeto mais ambicioso para a área, almejando desenvolver concomitantemente a sua indústria de hardware e software. Corroborando o que Wallerstein (2004) descreve que ocorre com os Estados semiperiféricos, o Estado indiano empreendeu medidas protecionistas para lograr seus objetivos. Entretanto, suas ambições foram frustradas. Isso ocorreu em parte devido à pressão interna de parte do próprio setor privado e da burguesia nacionais para a liberalização e a importação de produtos estrangeiros. Essa liberalização teve um efeito duplo: prejudicou a indústria de hardware nacional, mas catalisou a indústria de software doméstica.

As pressões internas, contudo, tiveram êxito principalmente graças a conjuntura da economia-mundo que era, até então, favorável. Ao longo da década de 1980 e 1990 a tolerância do centro para com as medidas protecionistas da semiperiferia terminou. A nova estruturação do sistema financeiro internacional, a pressão doméstica e externa pela adoção do corolário neoliberal e, por fim, a própria crise econômica que levou a Índia a contrair um empréstimo com o FMI, levaram a liberalização da economia indiana.

Apesar de não cumprir os objetivos iniciais do governo indiano, essa situação de catapultar a indústria de software (em detrimento da de hardware) acabou por servir aos interesses deste. As receitas auferidas com a indústria de software produziram a amenização do déficit no balanço de pagamentos.

Atualmente, a emergência de um novo padrão técnico-produtivo com o advento da Indústria 4.0, impactou na formulação de políticas para a 
indústria de software indiana. As atividades de software são uma parte crucial dentro desse novo modelo de produção industrial, principalmente as de maior complexidade tecnológica. Isso configura um incentivo ao país para que este desenvolva essas atividades. O plano de envergadura nacional para a atualização da matriz produtiva também impactou a indústria de hardware, até então relativamente marginalizada da estratégia nacional desde o seu desmonte. A Índia pretende se tornar um grande produtor de eletrônicos, sendo assim a área está ganhando um novo destaque nas políticas estatais. $E$ isso é importante para 0 desenvolvimento da indústria de software.

Como estamos nos referindo a processos recentes temporalmente, ainda não são certas as consequências dessas políticas e se elas lograrão realizar uma mudança estrutural na indústria de software indiana. O que podemos provisoriamente destacar é que a resposta indiana a esse novo padrão técnico-produtivo emergente está fomentando a formulação de políticas que tem o potencial de romper com as grades da gaiola dourada. Resta saber se poderão se tornar efetivas, no sentido de contribuírem para a alteração da forma de inserção da Índia na economia mundo capitalista, delineada neste artigo através do estudo do setor de tecnologia da informação.

\section{REFERÊNCIAS}

AHLUWALIA, Montek S. Indias economic reforms. India: The Future of Economic Reform. Oxford University Press: Oxford, United Kingdom, 1995.

ARORA, Ashish; ATHREYE, Suma. The Software Industry and India's Economic

Development Information. Economics and Policy, 2002.

ARRIGHI, Giovanni. A ilusão do desenvolvimento. Petrópolis: Vozes, 1997.

BANIK, Arindan; PADOVANI, Fernando. Índia em transformação: o novo crescimento econômico e as perspectivas pós-crises. pt. Revista de Sociologia e Política, Scielo, v. 22, p. 67-93, jun. 2014. Disponível em: $\leq$ http://www.scielo.br/pdf/rsocp/v22n50/06.pdf $>$. 
BARBOSA, Marcel Jaroski. Crescimento econômico da Índia antes e depois das reformas de 1985/1993. 2008. Diss. (Mestrado). Faculdade de Administração, Contabilidade e Economia. Disponível em: $\leq$ http://tede2.pucrs.br/tede2/handle/tede/3855 $\geq$.

CLINGINGSMITH, David; WILLIAMSON, Jeffrey G. Deindustrialization in 18th and 19th century India: Mughal decline, climate shocks and British industrial ascent. Explorations in Economic History, Elsevier, v. 45, n. 3, p. 209-234, 2007.

D'COSTA, Anthony P. Export growth and path-dependence: the locking-in of innovations in the software industry. In: INDIA in the global software industry. [S.I.]: Springer, 2004. p. 51-82.

GOI. Government of India. < http://data.gov.in/node/88140/download_. Acesso em: 10 dez 2019.

GOPALAKRISHNAN, Kris S. Indian IT and ITeS journey: Liberalization and beyond. [S.I.: s.n.], 2016. < https://www.livemint.com/Opinion/fNjocJ9cwIGCDqLWt2OjXP/Indian-ITand-ITeSjourney- Liberalization-and-beyond.html $\geq$. Acesso em 22 dez 2019.

IEDI. Indústria 4.0: O programa Make in India e outras iniciativas do governo indiano - Ed. 849. São Paulo - SP, mai. 2018a.

IEDI. Princípios de um Plano para a Indústria 4.0 no Brasil - Ed. 862. São Paulo - SP, jul. 2018b.

KRISHNAN, Rishikesha T. The evolution of a developing country innovation system during economic liberalization: the case of India. The First Globelics Conference, 2003.

NASSIF, André. A economia indiana no período 1950-2004: da estagnação ao crescimento acelerado: lições para o Brasil? [S.I.]: Área de Planejamento, Departamento de Planejamento (DEPLAN), BNDES, 2006. v. 107.

NORTON, Robert. Catalytic Corruption: The Domestic Software Services Boom, 1978-86. In: DOT.COMPRADORS: Crisis and Corruption in the Indian Software Industry(IIPPE). London - UK: Pluto Press, 2012. p. 49-58.

PARTHASARATHI, Ashok; JOSEPH, KJ. Innovation under export orientation. In: INDIA in the Global Software Industry. [S.I.]: Springer, 2004. p. 83-111.

PRATES, Daniela Magalhães; CINTRA, Marcos Antônio Macedo. Índia: a estratégia de desenvolvimentoda independência aos dilemas da primeira década do século XXI. $\ln$ :

TRAJETÓRIAS recentes de desenvolvimento: estudos de experiências internacionais selecionadas. Brasil: IPEA, jun. 2013. p. 397-453.

RBI. Reserve Bank of India. [S.I.s.n], 2019. <https://www.rbi.org.in/ $\geq$. Acesso em 19 dez 2019. 
ROSELINO, José Eduardo de Salles. A industria de software : o modelo brasileiro em perspectiva comparada. Fev. 2006. Tese (Doutorado) - Universidade Estadual de Campinas (UNICAMP). Acesso em: 6 dez. 2019. Disponível em: $\leq$ http://repositorio.unicamp.br/jspui/handle/REPOSIP/286219 $>$.

ROY, Arundhati. Manna from heaven: Satellites, Optic Fibres and the Export Thrust, 1986 2000. In: DOT.COMPRADORS: Crisis and Corruption in the Indian Software Industry (IIPPE). London - UK: Pluto Press, 2012. p. 59-66.

RUVALCABA, Daniel Morales. The Semiperipheral States in the Twenty-first Century: Measuring the Structural Position of Regional Powers and Secondary Regional States. International Studies, v. 57, n. 1, p. 20-50, 2020. Disponível em: $\leq$ https://doi.org/10.1177/0020881719880769 >.

SARASWATI, Jyoti. Dot.compradors: Crisis and Corruption in the Indian Software Industry (IIPPE). London - UK: Pluto Press, 2012.

SINGH, Ishmeet; KAUR, Navjot. Contribution of information technology in growth of Indian economy. International Journal of Research - Granthaalayah, v. 5, n. 6, p. 1-9, jun. 2017. Disponível em: $\leq$ https://doi.org/10.5281/zenodo.805859 $\geq$.

SO, A.Y.; CHIU, S.W. East Asia and the world economy. California - USA: Sage Publications, 1995. (Sage Library of Social Research).

SOLANKI, Deepak Kumar; SINHA, Kunal. Innovation and Development in Information Technology in India: Specific to Software Industry. Journal of Technology Management for Growing Economies, v. 8, n. 2, p. 129-144, out. 2017. Disponível em: $\leq$ https://tmg.chitkara.edu.in/index.php/tmge/article/view/17 $\geq$.

SRIDHARAN, Dr E. India in the Global Software Industry: Innovation, Firm Strategies and Development. In: INDIA in the Global Software Industry. [S.I.]: Springer, 2004. p. 51-82.

STATISA. 2020 Disponível em: < https://www.statista.com/statistics/320729/india-itindustry-direct-indirect-employment/_>. Acesso em 28 ago 2020.

STEFANUTO, Giancarlo Nuti. O programa softex e a industria de software no Brasil. Ago. 2004. Tese (Doutorado) - Universidade Estadual de Campinas (UNICAMP). Acesso em: 2 dez. 2019. Disponível em: $\leq$

http://repositorio.unicamp.br/jspui/handle/REPOSIP/286728 >.

VIEIRA, Maíra Baé Baladão. Relações Brasil-Índia (1991-2006). Editora UFRGS, Porto Alegre - RS, 2009.

VIJAYASRI, GV. The role of information technology (it) industry in India. v. 2. Delhi India: Abhinav, 2013. p. 54-64.

VIRMANI, Arvind et al. The dynamics of competition: Phasing of domestic and external liberalisation in India. Planning Commission Working Paper, n. 4, 2006. 
WALLERSTEIN, Immanuel. Análisis de Sistemas-Mundo: Una Introducción. USA: Duke University Press, 2004. (A John Hope Franklin Center book). Acesso em: 20 jul 2019. Disponível em: $\leq$ https://sociologiadeldesarrolloi.files.wordpress.com/2014/11/223976110-26842642immanuel-wallerstein-analisis-de-sistemas-mundo.pdf $\geq$.

WALLERSTEIN, Immanuel. The Modern World-System III: The Second Era of Great Expansion of the Capitalist World-Economy, 1730s1840s. 1. ed. USA: University of California Press, 2011. Disponível em: <http://www.jstor.org/stable/10.1525/j.ctt1ppb70_>.

WALLERSTEIN, Immanuel. The capitalist World-Economy. New York: Cambridge University Press, 1979.

\section{NOTAS DE AUTOR}

\section{CONTRIBUIÇÃO DE AUTORIA}

Daniela Santos Nunes de Rodrigues - Concepção. Coleta de dados, Análise de dados, Elaboração do manuscrito, revisão e aprovação da versão final do trabalho

Helton Ricardo Ouriques - Análise de dados, Elaboração do manuscrito, revisão e aprovação da versão final do trabalho

\section{FINANCIAMENTO}

Essa pesquisa é resultado da dissertação de Mestrado da autora Daniela Santos Nunes de Rodrigues, orientada pelo Professor Helton Ricardo Ouriques com o apoio financeiro na forma de bolsa de estudos financiada pela Coordenação de Aperfeiçoamento de Pessoal de Nível Superior (CAPES) entre 01/02/2019 e 29/02/2020.

\section{CONSENTIMENTO DE USO DE IMAGEM}

Não se aplica.

\section{APROVAÇÃO DE COMITÊ DE ÉTICA EM PESQUISA}

Não se aplica.

\section{CONFLITO DE INTERESSES}

Não se aplica

\section{LICENÇA DE USO}

Este artigo está licenciado sob a Licença Creative Commons CC-BY. Com essa licença você pode compartilhar, adaptar, criar para qualquer fim, desde que atribua a autoria da obra.

\section{HISTÓRICO}

Recebido em: 31-08-2020

Aprovado em: 18-12-2020 